\title{
GOOD CORPORATE GOVERNANCE PRINCIPLES IN THE MANAGEMENT OF LIMITED LIABILITY COMPANY
}

\author{
Henry Aspan \\ Universitas Pembangunan Panca Budi \\ henryaspan323@gmail.com
}

\begin{abstract}
Corporate governance is a concept which still debatable among experts in describing it. The purpose of this study is to explore how the implementation and principle problems of good corporate governance in the management of current limited liability company. This research is kind of library research with normative juridical approach, the approach used was the concept of legit positivism which states that the law is identical to written norms established and enacted by authorized bodies or authorities. The result is known that Law Number 40 Year 2007 regarding Limited Liability Company does not explicitly regulate the implementation of Good Corporate Governance principles. The Good Corporate Governance principle setting is explicitly found only in the Regulation of the Minister of State-Owned Enterprises and Bank Indonesia Regulation, so it does not bind the limited liability company in general.

Keywords: Company Law, company, business law, Stated-Own Enterprise

\section{A. Introduction}

Implementation of good corporate governance principles in companies in Indonesia is expected to be one of the ways out of the prolonged economic crisis. Through the application of Good Corporate Governance principles, it is hoped that the collapse conglomerate companies can immediately survive. Similarly, companies which are not included in the monitoring and restructuring program, in order to survive and have a high competitiveness both in local and global competition. This is because the existence of the company has multiplier effects, so it is much related and affects the various fields, especially the field of economic society in a broad scope.
\end{abstract}


Based on statistical data, the number of listed companies in Indonesia is currently 23,941 companies, small, medium, and large, and every day continues to grow. ${ }^{1}$ In addition there are 122 State-Owned Enterprises (SOEs) in the form of limited liability companies. ${ }^{2}$ From that number, based on data released by Indonesia Stock Exchange, there are 507 publicly-listed public companies (PT Tbk.) or sell their shares to the public through the stock exchange.

In the long term the implementation of Good Corporate Governance, it can improve the performance or value of the company, thereby increasing investor confidence, benefiting shareholders (in this case the value of shares and dividends received will increase), and provide effective protection for shareholders and creditors so they are confident of obtaining Return on their investment/loan.

Seeing the problems faced by the company, both internal and external, the principle of good corporate governance should be implemented, and there must also be a strong legal basis for its implementation. Formally legal, the provisions on Good Corporate Governance principles have not been explicitly regulated in the Law of Ltd Year 2007. So the problem that arises is the weakness of effectiveness and strength of Good Corporate Governance implementation.

Especially for State Owned Enterprises (BUMN), the implementation of the principles of good corporate governance is regulated through the Regulation of the Minister of State-Owned Enterprises. In this case, the application of GCG principles is an obligation in the effort to realize good corporate governance. On that

${ }^{1}$ Central Bureau of Statistics, Number of Large-Medium Manufacturing Enterprises 20082013 According to Subsector, in www.bps.go.id., accessed on January 1, 2015.

${ }^{2}$ Analyzed based on BUMN data with Persero classification not including Perum. See www.bumn.go.id accessed on January 1, 2015. 
basis, the Minister of State-Owned Enterprises then issued the Regulation of the Minister of State-Owned Enterprises No. Per-01 / MBU / 2011 on the Implementation of Good Corporate Governance Principles (GCG) in State-Owned Enterprises (BUMN).

Furthermore, concerning on the implementation of the principles of good corporate governance (GCG) which is a form of corporate governance to create good corporate management, in fact still have problems in its implementation. Using the legal system theory developed by Lawrence M. Friedman, the principles of good corporate governance must be bound in a legal system, consisting of three elements: legal substance, legal structure, and legal culture. It is intended that the application of the Good Corporate Governance principle is not only limited to the general terms or conditions which only serve as a guideline without any legal investment in the provisions on good corporate governance based on Good Corporate Governance principles.

Good Corporate Governance Principle should be established in the formal legal provisions to provide a capable juridical force of binding any limited liability company (read PT in Indonesian) consisting of corporate organs, including Board of Directors, Board of Commissioners, and shareholders, to prioritize Good Corporate Governance principles in conducting activities Management of Ltd.

The research paradigm of this research start from the weak implementation of the principle of good corporate governance (GCG) as something that should bind the limited liability company (PT) as a whole. The Good Corporate Governance Principles which are not explicitly stipulated in Law Number 40 Year 2007 regarding Limited Liability Company (Ltd Law year 2007) open the gap for the existing Ltd not to implement the principle of Good Corporate Governance. 
Currently, only State-Owned Enterprises (BUMN), Ltd in the banking sector, and Open Ltd (PT Tbk) are clearly applying Good Corporate Governance principles as guidelines in the governance of the company. Therefore, it is important to review this Good Corporate Governance principle as a principle of good corporate governance. By implementing this Good Corporate Governance principle, each company is designed to be more professional in terms of management governance and corporate performance governance.

\section{B. Discussion}

\section{Implementation of Good Corporate Governance Principles in the Management of Limited Liability Companies}

Implicitly, the principles of good corporate governance (GCG) are discussed in the fifth principle of Pancasila namely "Social Justice for all Indonesians". This concept is translated in order to realize the national development in the economic field in order to guarantee the values of justice in its implementation. Pancasila is then translated into the constitutional norm of the Indonesian nation, namely the 1945 Constitution of the Republic of Indonesia (Constitution of the Republic of Indonesia). The Indonesian Constitution in Article 33 describes the economic principles in order to realize development, both in the economic field and in Governance in order to realize economic independence.

As the highest legal norm, the 1945 Constitution requires a good handling of governance in the economic field through the strengthening of good management system for the company as an instrument to demonstrate economic independence. Thus Good Corporate Governance principles can not be separated from the study that the values of Good Corporate Governance is fully an incarnation of the values of Pancasila and the 1945 Constitution. 
In addition to the study of the concept of Good Corporate Governance according to Pancasila, it is also necessary to discuss the study of the concept of Good Corporate Governance according to Islamic values, which has a comprehensive and comprehensive concept, to maintain akhlaqul karimah and piety to Allah SWT, which all these things are intended to avoid people from doing illegal and dishonest in accepting the mandate. Good corporate governance itself, which in modern terminology is called as good corporate governance related to the hadith of the Prophet SAW narrated by Aisha r.a which means "Indeed God likes when someone does something in a good way".

Muqorobin states that good corporate governance in Islam should refer to the following principles: ${ }^{3}$ The first principle of monotheism, which is the main foundation of all Islamic teachings. Tauhid became the basis of all concepts and all activities of Muslims, in the economic, political, social and cultural fields: ${ }^{4}$ In the Qur'an, it is mentioned that monotheism is a fundamental philosophy of Islamic Economics, as the word of God in the letter $A z$-Zumar Az 38: "And if you ask them: Who created the heavens and the earth? Say: "Then explain me what you call besides Allah, if Allah will bring harm to Me, Will your idols be able to eradicate that harm, or if Allah will grant mercy to Me, Can they hold His grace? Say:" Suffice it God to me "to Him with those who surrender".

The second principle is taqwa (piety) and ridha (willing), which is the main principle of establishment of an Islamic institution in any field. Therefore, business governance in Islam must also be established on the foundation of piety towards Allah and His pleasure

3 Muqorobin Masyudi, 2010, Fikih Tata Kelola Organisasi Laba: Sebuah Pengantar, Universitas Muhammadiyah Purwokerto, Purwekerto, page 4

${ }^{4}$ Amiur Nuruddin dan Veithzal Rivai, 2012, Islamic Business and Economic Ethic, Bumi Aksara, Jakarta, page 32 
in QS at-Tawbah: 109, which means "Are those who build their mosque on the basis of taqwa to Allah and His mercy, that is better, or the men who build the building on the edge of the abyss that collapses, and the building falls with him into Hell's Fire. And Allah does not guide those who do wrong. "

The third principle is tawazun or mizan (equilibrium) and al'adalah (justice), namely the concept of equilibrium in Islam. Tawazun is more widely used in explaining physical phenomena, although it has social implications, which then often become al-'adalah or justice areas as manifestations of Tauhid especially in the social context, including economic and business justice. Allah SWT says in QS arRahman verses 7-9: which means "And Allah has lifted up the heavens and He laid the balance sheet (justice). So you do not go beyond the limit on the balance sheet. And establish the scales justly and do not reduce the balance sheet ".

The fourth principle is favor. In general, mashlahat (favor) is defined as the good (prosperity) of the world and the hereafter. The ushul fiqh scholars defined it as anything that contains merit, goodness and avoid mudharat (injured), damage and mufsadah. Imam al-Ghazali concluded that mashlahat is an effort to realize and maintain the five basic needs, namely: religious maintenance ( hifdzuddin); Maintenance of the soul (hifhzun-nafs); Maintenance of reason (hifhzul-'aq); Maintenance of posterity (hifhzun-nas); And Maintenance of property ( hifhzul-maa). ${ }^{5}$

In addition to study the concept of Good Corporate Governance from the point of view of Pancasila, the 1945 Constitution of the State of the Republic of Indonesia, as well as the teachings of Islam, this research also examined the application of the Good Corporate

${ }^{5}$ Amiur Nuruddin dan Veithzal Rivai, 2012, Op. Cit, page 58 
Governance concept in several countries. The first country is India. As a developing country, India is a country that is active in applying the principles of good corporate governance (GCG) to the governance of companies in the country. Since the 1990s companies in India have been encouraged to adopt international rules regarding the implementation of Good Corporate Governance as a principle of good corporate governance. ${ }^{6}$

The Good Corporate Governance arrangements in India are contained in the Company Act $1956,{ }^{7}$ and the guidance regulations issued by the Security and Exchange Board of India (SEBI) as the capital market regulator in India. The Company Law is run by the Ministry of Corporate Affairs (MCA). The Reserve Bank of India (RBA) and the Insurance Regulatory Development Authority (IRDA) also established GCG policies that apply to banking and insurance companies. The existence of SEBI plays an important role in establishing corporate governance norms in India.

The second country is Malaysia. In Malaysia, the rules governing the implementation of corporate governance were first released in March 2000, which is a major milestone in corporate governance reform in Malaysia. This rule was subsequently revised in 2007 to strengthen the roles and responsibilities of boards of directors, audit committees, and internal audit functions.

The Malaysian corporate governance principle of 2012 (MCCG 2012) focuses on strengthening board structures and the composition of the roles of directors and fiduciary responsibilities. The Board of Directors has the duty to provide effective service for the company as well as to be a corporate bodyguard, not just to set the company's

${ }^{6}$ Confederation Of Indian Industry, Desirable Corporate Governance: A Code, (1998).

7 Companies Act Establishes a basic regulatory framework governing all firms in India, including those relating to the incorporation, functioning and closure of Indian firms. 
strategic direction and to oversee the company's business operations. The Board of Directors must also ensure that the company in conducting its business must be law-abiding and maintain ethical values, and maintain effective governance to ensure risk management and internal control levels.

Based on Malaysia Good Corporate Governance 2012, there are 8 principles in good corporate management, namely (1) Building clear roles and responsibilities; (2) Strengthening of the composition; (3) Strengthen independence; (4) Foster commitment; (5) upholding integrity in financial reporting; (6) Know and manage risk management; (7) Ensuring timely high quality disclosure; And (8) Strengthening the relationship between the company and shareholders. ${ }^{8}$

The third country is Singapore. Singapore was the $2^{\text {nd }}$ ranked after the Hong Kong state, with a score of 92.9 on Good Governance for International Business Index In Asia Pacific for 2010, and also ranked 2nd in the Global Competitiveness Index 2013-2014. Both of the above assessments are the programs used to measure how well the governance of a country is based on the principles of good governance (transparency, accountability, effectiveness, efficiency, and other aspects).

2. Problems in the Implementation of Good Corporate Governance Principles in Limited Liability Companies

There are 4 (four) negative assessments related to the application of Good Corporate Governance principles in Indonesia. First, few people are convinced that the government is serious about encouraging the implementation of Good Corporate Governance

${ }^{8}$ PWC Alert, Malaysian Codes on Corporate Governance 2012, Issue 103 Agustus 2012, page. 5-8. 
principles. Second, in the eradication of corruption the government faces credibility issues. Third, information disclosure is still weak, especially about material events, stock transactions from directors, lack of investor involvement, and still many companies stand against Good Corporate Governance principles. Fourth, law enforcement by the regulator is still weak and less independent of self-regulatory organization (SRO). However, there are also some positive assessments regarding the implementation of Good Corporate Governance principles. First, the quarterly reports of public companies are considered good, Second, adequate protection for minority shareholders. Third, the anti-corruption policy has shown tangible results. Fourth, Indonesia continues to make improvements related to the implementation of Good Corporate Governance principles through the refinement of "Good Corporate Governance Guidelines" and "Guidelines for Banking Sector".

It is not difficult to find examples of such weaknesses. For example, government support for the National Committee on Governance Policy (KNKG), historically formed by the government, now shows a level that is not as strong as in the early days of its formation. In addition, in eradicating corruption quite a lot still doubt the integrity of law enforcement. Law enforcement by regulators, especially the Financial Services Authority (read OJK in Indonesian language), is not maximized either by juridical or non-juridical obstacles.

In the implementation of Good Corporate Governance principles there are 3 (three) responsible parties namely, the state organizers (including the executive, legislative, and judicial), the business community, and society. State organizers should create a conducive environment that is a prerequisite for good corporate governance, for 
example by providing legislation and policies that support a healthy, efficient and transparent business climate, and consistent enforcement of law enforcement. While the business world and society should apply Good Corporate Governance principles well. Communities must also participate and exercise social control over corporate compliance in applying Good Corporate Governance principles. ${ }^{9}$

Second, the law in the perspective of social engineering, is the most widely used of the officials (the officials perspective of the law) to explore the sources of power that can be mobilized by using the law as its mechanism. Quoting opinion from advocates of this social engineering by law perspective, Satjipto Rahardjo argues that there are four main requirements that must be met in order for a rule of law to be social engineering that is, (1) a good description of a situation at hand; (2) an analysis of the assessment and determination of the level of values; (3) verification of hypotheses; (4) the measurement of the effect of applicable law. ${ }^{10}$

Satjipto Rahardjo sees the legal culture as the foundation for the implementation or non-implementation of a positive law in society, because the implementation of positive law is largely determined by the attitudes, views, and values shared by the community. ${ }^{11}$ Therefore, the legal culture for modern society with open system will be different from traditional closed society law culture. As for the progressive society he calls the culture of personal law as the embodiment of the tendency to treat the law and its institutions in an easy and personal way. The legal culture is one component to understanding the workings of the legal system as a process, in which

${ }^{9}$ Yunus Husein, Penguatan Good Governance, Harian Sindo, 24 Desember 2007, page 6.

10 Satjipto Rahardjo, 1977, Pemanfaatan Ilmu Sosial Bagi Pembangunan Ilmu Hukum, Alumni, Bandung

${ }^{11}$ Satjipto Rahardjo, 1980, Hukum dan Masyarakat, Bandung, Angkasa, page. 85. 
legal culture serves as a 'fuel' for motor justice. Thus without the support of a conducive legal culture, it will be difficult for a law or regulation to be realized as expected by both lawmakers and the public as the target of the law.

Assessing legal culture in the perspective of positive law, where the law prevailing in society in the form of legislation, requires equivalence on the elements contained in the law itself that guide how the law can be formulated, organized, and then applied. In this case, the legal culture, defined as the values and attitudes of members of the public associated with the law, has a very important role for the working or non-working of law in society. The legal culture is an accurate legal element and is commensurate with the objective of answering the effectiveness of law, in the study of law and society, rather than the conventional method of studying the law from the historical aspect alone. ${ }^{12}$ Through a set of values, habits, and behaviors can be shown how the rules of law are perceived in a logical and rational by society. ${ }^{13}$

The legal culture is an accurate legal element and is commensurate with the objective of answering the effectiveness of law, in the study of law and society, rather than the conventional method of studying the law from the historical aspect alone. Through a set of values, habits, and behaviors can be shown how the rules of law are perceived in a logical and rational by society.

\section{Conclusion}

Implementation of good corporate governance (GCG) principles has been implemented in Indonesia. However, the GCG practice is not

\footnotetext{
${ }^{12}$ Lawrence M.Friedman \& Stewart Macaulay, 1977, Law And Behavioral Science, The Bobbs Memill Company Inc, New York, page 1028-1031.

${ }^{13}$ Ibid., page 858
} 
explicitly regulated in Law Number 40 Year 2007 regarding Limited Liability Company for the company in general. The obligation to apply Good Corporate Governnance principles is still limited only to companies of state-owned enterprises (SOEs), banks, and public companies (companies that sell their shares in the capital market) regulated through the Regulation of the Minister of State-Owned Enterprises and the Regulations of the Governor of Bank Indonesia.

The problematic implementation of good corporate governance (GCG) principles in Indonesia is that the conditions of good corporate governance culture have not been established in many limited liability companies. This can be seen from the number of companies built with the orientation of pursuing self-interest solely, where the violations of corporate governance is done not only by directors and commissioners, but also by all organs of the company. So if the Good Corporate Governnance principles are applied consistently in the company, it will certainly further limit the evil intentions of the elements within the company. This is also coupled with the concrete yet and explicit rules that force companies to adopt Good Corporate Governnance principles as guidelines for corporate governance. The lack of clarity of this rule would make the government's control over limited liability Company weak, which in turn gave birth to many companies that are just Paper Company only.

In order to prevent the difficulties of applying the principles of good corporate governance (GCG) to the company, it is necessary to have supervision starting from the company registration level until the ongoing supervision in the form of annual report of Good Corporate Governnance implementation carried out by a special agency appointed by government. In addition to strengthening oversight of GCG implementation, the commissioner's function can be strengthened by appointing an 
independent commissioner who is not affiliated with the interests of any party except on the interests of the company as a whole.

A principle of good corporate governance (GCG), which has only been the norm without power force, is the cause of the weak implementation of these principles in corporate governance. So with the change of Good Corporate Governnance principles from mere norms into concrete and explicit rules, it is hoped that the implementation of those principles will have force.

\section{References}

Arief, B.N. 2010. Masalah Penegakan Hukum dan Kebijakan Hukum Pidana dalam Penanggulangan Kejahatan. Kencana Pranada Media Grup. Jakarta.

Bloch, Ernst, Dennis J Schmidt. 1996. Natural Law adn Human Dignity, Third Edition. MIT Press, USA.

Friedman, Lawrence M. \& Stewart Macaulay. 1977. Law And Behavioral Science. The Bobbs Memill Company Inc. New York.

Friedman, Lawrence M. 1975. The Legal System A Social Perspective. Russel Sage Foundation. New York.

Friedman, W. 1990. Teori dan Filsafat Hukum. PT. Rajawali Press. Jakarta.

Griffiths, Andrew. 2005. Contracting with Companies. Hart Publishing, Portland.

Griffiths, Andrew. 1995. Shareholding and The Governance of Public Companies, dalam Corporate Goverance \& Corporate Control, diedit oleh Saleem Sheikh and William Rees. Cavendish Publishing Limited. London.

Hart, H.L.A, 1972. The Concept of Law. The English Language Book Society and Oxford University Press. London.

Hartono, Sri Rejeki, et.al, ed. 2006. Permasalahan Seputar Hukum Bisnis: Persembahan kepada Sang Maha Guru, Tanpa Penerbit. Yogyakarta.

Masyudi, Muqorobin. 2010. Fikih Tata Kelola Organisasi Laba: Sebuah Pengantar. Universitas Muhammadiyah Purwokerto. Purwekerto.

MD, Mahfud. 2001. Politik Hukum di Indonesia. LP3ES. Jakarta.

Nuruddin, Amiur dan Veithzal Rivai. 2012. Islamic Business and Economic Ethic. Bumi Aksara. Jakarta.

OECD. 2005. Corporate Governance of Stated Owned Enterprises. OECD Publishing, US. 
Otoritas Jasa Keuangan. 2013. Roadmap Tata Kelola Perusahaan Indonesia. OJK. Jakarta.

Rahardjo, Satjipto. 1980. Hukum dan Masyarakat. Bandung: Angkasa, Rahardjo, Satjipto. 1977. Pemanfaatan Ilmu Sosial Bagi Pembangunan IImu Hukum. Alumni. Bandung.

Rahardjo, Satjipto. 2010. Penegakan Hukum Progresif. Kompas. Jakarta. Rahardjo, Satjipto. 2007. Biarkan Hukum Mengalir: Catatan Kritis Tentang Pergulatan Manusia dan Hukum. Penerbit Buku Kompas. Jakarta.

Rahardjo, Satjipto. 2009. Penegakan Hukum Suatu Tinjauan Sosiologis. Genta Publishing. Yogyakarta. 